\title{
Sequence stratigraphic subdivision of the Oligocene and Miocene succession in South Jutland
}

\author{
ERIK SKOVBJERG RASMUSSEN
}

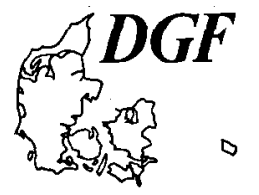

\author{
Rasmussen, E. S.: Sequence stratigraphic subdivision of the Oligocene and Miocene \\ succession in South Jutland. Bulletin of the Geological Society of Denmark, \\ Vol 43, pp. 143-155. Copenhagen, 1996-12-05. \\ https://doi. org/10.37570/bgsd-1996-43-14
}

\begin{abstract}
The present study is based on seismic data and log interpretation from six wells located in the southern part of Jutland (Denmark). The Oligocene and Miocene succession has been subdivided into six depositional sequences. Most of the se-quences are of Type 1. The development of the Oligocene and Miocene sequences suggests a strong relationship with glacio-eustatic sea-level variations. Each se-quence consists of a lowstand systems tract, which either corresponds to detached prograding intervals or coarse-grained deposits, a transgressive systems tract, and a highstand systems tract. Changes in the overall pattern of the Oligocene and Miocene succession, however, suggest variation in elevation of the hinterland due to different uplift of Fenno-Scandia and Baltic Shields. The depositional environ-ment was characterized by shelf and nearshore sediments in a rapidly changing environment where the shoreline migrated/retreated across South Jutland several times.
\end{abstract}

Key words: Sequence stratigraphy, Oligocene, Miocene, Denmark.

E. S. Rasmussen, GEUS, Geological Survey of Denmark and Greenland, Thoravej 8, DK-2400 Copenhagen NV, Denmark. 28th September 1995.

South Jutland shows one of the most complete Miocene succession in onshore Denmark. Overlying the relatively thin Oligocene deposits (probably latest Late Oligocene age) there is an almost complete Miocene succession of alternating sand - and clay units reflecting a relatively dynamic environment of changing terrestrial, nearshore and shelf deposits. Generally, the

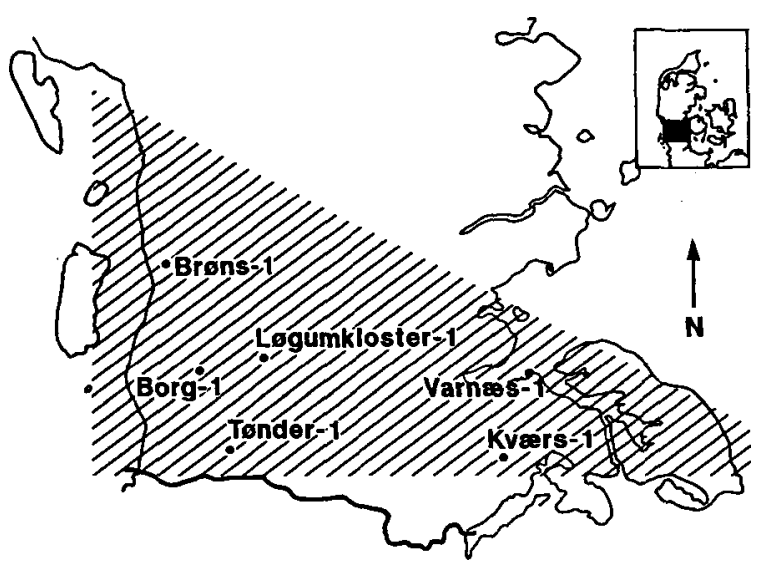

Fig. 1. Study area and the wells used in the study.
Oligocene and Miocene of onshore Denmark has been well studied. A well defined and well dated lithostratigraphic subdivision of the Tertiary has been established by Sorgenfrei $(1940,1958)$, Larsen \& Dinesen (1959), Rasmussen (1961), Christensen \& Ulleberg 1973, 1974, Dinesen, Michelsen \& Lieberkind (1977), Ulleberg (1987), Buchardt-Larsen \& Heilmann-Clausen (1988), and Koch (1989). The present paper attempts to establish a sequence stratigraphic framework of the Oligocene and Miocene succession of South Jutland and to discuss possible causes for the formation of each identified sequence. The study area is shown in Fig. 1 and the established lithostratigraphy of Denmark is shown in Fig. 2.

\section{Geological setting}

The very early Tertiary of Denmark was influenced by inversion tectonics in northwest Europe (Sorgenfrei 1951, Ziegler 1982, Liboriussen, Ashton \& Tygesen 1987). Thus former grabens were inverted and block faulting occurred especially along the SorgenfreiTornquist zone. The paleoenvironment environment 


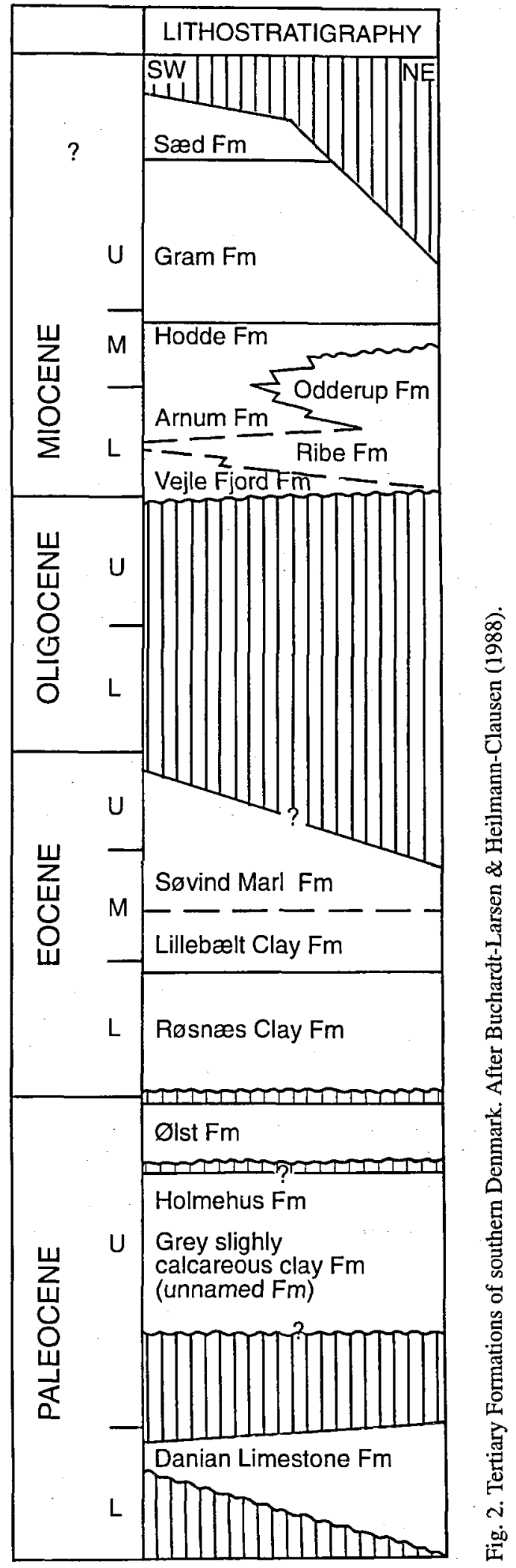

was characterized by deposition of shallow marine carbonates either as biogenic deposits or reworking of older carbonates on uplifted blocks. At the end of the Danian basement-related tectonic movements ceased and except from minor events at the end of the Paleocene, only movements related to salt tectonics occurred. These, however, continued throughout the Tertiary (Heilmann-Clausen, Nielsen \& Gersner 1985). From the Late Paleocene, clastic sedimentation characterized the depositional environment and during the Late Paleocene and most of the Eocene, very finegrained sediments (swelling clay) accumulated in a marine environment. Variations in the depositional environment were caused by changes in sea-level or circulation pattern of the former North Sea (e.g. Bonde 1979, Pedersen \& Surlyk 1983, Heilmann-Clausen et al. 1985). Volcanic activity adjacent to the area during the latest Paleocene and the early Eocene is reflected in a number of interbedded ash layers. At the end of the Middle Eocene or earliest Late Eocene, the supply of silt increased in the southern part of Jutland and northern part of Germany (Gripp 1964). The Late Eocene and Early Oligocene sedimentary succession is incomplete in the Danish area. Whether this is due to non-deposition or to erosion is uncertain, but clear evidence of late Oligocene-Neogene uplift of FennoScandia has been reported by Jensen \& Schmidt (1992), Japsen (1993), Michelsen \& Nielsen (1993), and Rohrman, Andriessen \& van der Beek (1996). Reworking of older Tertiary sediments during the Neogene has been suggested by Rasmussen \& Larsen (1989) and the influx of coarse-grained clastics is documentated by Larsen \& Dinesen (1959) and Rasmussen (1987). The transition from the Paleogene to the Neogene is an important phase in the development of the eastern North Sea Basin and of the sedimentary succession onshore Denmark.

The distinct uplift of Fenno-Scandia (up to $1200 \mathrm{~m}$ in eastern Denmark (Japsen 1993)) resulted in a marked increase of coarse-grained clastics in the southwestern part of the Danish area. A complex succession of alternating terrestial-nearshore and shelf deposits were laid down. The general transport direction is thought to have been from the east and north (Cameron, Bulat \& Mesdag 1993, Torben Bidstrup Pers. Comm. 1994). Minor salt-related structuring may have had local influence on the depositional environment as did the Ringkøbing-Fyn High which influenced the outline of the coast in the Early Miocene (Sandersen 1985).

Climatic conditions were warm and humid in the Paleocene and most of the Eocene (Bonde 1979, Buchardt 1978, Collison, Fowler \& Boulter 1981). At the end of the Eocene a cooler period was initiated and continued during most of the Oligocene. Warm-temperate and humid climatic conditions prevailed during the Miocene (Sorgenfrei 1958, Koch 1989). 


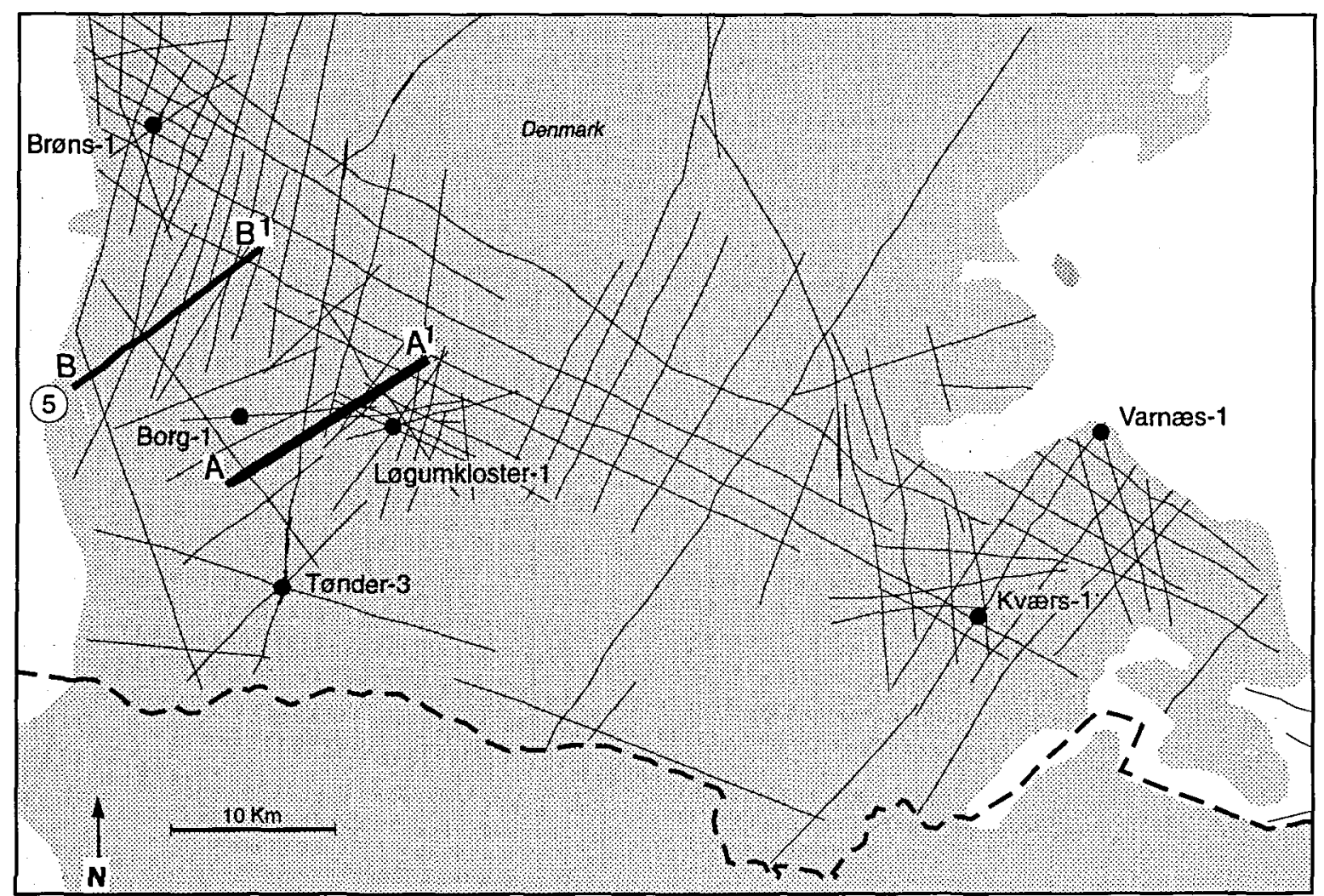

Fig. 3. Seismic surveys and wells used in the study. The two geosections shown in figure 4 are marked with heavy lines.

\section{Data and method}

The seismic data used in the present study are selected lines of the 1978 to 1981, GC85T, and ST87T surveys (Fig. 3). The gamma logs from 6 wells; Tønder-3, Løgumkloster-1, Borg-1, Brøns-1, Kværs-1, and Varnæs1 are used for correlation and identification of key surfaces. The interpretation of seismic data is based on principles of seismic facies analysis (Vail, Mitchum, Todd, Widmier, Thompson, Sangree, Bubb \& Hatelid 1977, Brown \& Fisher 1980) and following the principles of sequence stratigraphy (Jervey 1988, Posamentier \& Vail 1988, Posamentier, Jervey \& Vail 1988, Van Wagoner, Mitchum, Campion \& Rahmanian 1990) the sediments have been subdivided into genetically related packages separated by chronostratigraphic surfaces.

The construction of a relative sea-level curve is based on definitions of Posamentier, Jervey \& Vail (1988) and Jervey (1988) with modifications by Hunt \& Tucker (1992) and Helland-Hansen \& Gjelberg (1994). Rates of sedimentation are estimated from the thickness of each sequence (compacted) and time duration inferred from this study.

\section{Seismic study}

Two geo-profiles have been constructed based on seismic lines (Fig. 4). The geo-profiles show the overall architecture of the Oligocene and Miocene succession which will be described in detail below. It appears that the succession is faulted. The fault activity, however, occurred late in the Tertiary and probably during the Quaternary and did not distinctly influence the depositional environment during the deposition of the Oligocene and Miocene succession. Minor activity occurred also during the Oligocene as a complete Eocene section is preserved in the Borg-1 well located in a hangingwall position (Erik Thomsen pers. comm. 1994).

Based on a seismic study, the Oligocene and Miocene succession can be subdivided into four seismic units A, B, C, and D (Figs 4-5). Unit A is characterized by gently southwestward dipping clinoforms downlapping the major unconformity of the Paleogene deposits. The unit pinch-out in the southwestern part of the study area. In the northwestern part of the study area, a local seismic unit is recognised, unit B (Figs 4b-5). This unit shows an offlap stratal pattern characterized by high amplitude reflectors. In the northeastern part, the unit erosionally cuts into unit $\mathrm{A}$, but otherwise it show 
downlap onto the lower boundary. This unit also pinches-out towards the southwest. Unit $C$ is characterized by a parallel reflection pattern which onlap unit $A$ and unit $B$ where the latter is distributed. The uppermost unit, unit $\mathrm{D}$, shows a quite chaotic reflection pattern.

\section{Sequence stratigraphic subdivision}

The Oligocene and Miocene succession has been subdivided into 6 sequences, named SJOM1 to SJOM6 (Fig. 6). SJOM refer to South Jutland OligoceneMiocene succession.

The boundary between the Eocene and the Oligocene deposits is very distinct both on well logs and on seismic data. Lithologically, the boundary is characterized by a change from marl to glauconitic clay. This change can be recognized on the gamma log by a distinct peak (Fig. 6). From outcrops, this boundary shows rip-up clasts of the underlying marl and the surface is intensively bioturbated (e.g. Rasmussen 1987). Biostratigraphically, the hiatus covers the early Oligocene in this part of Denmark. The sequence SJOM1 is generally characterized by an upward decrease in gamma log response most evident in Brøns-1 and Løgumkloster-1. The maximum flooding surface is placed closed to the lower sequence boundary within the gamma peak which represents the glauconitic clay. Above the gamma peak, a gradual upward decrease in gamma log response characterizes the sequence. In the wells Brøns-1 and Løgumkloster-1, a two step decrease is seen and thick sand intervals have also been reported from these levels in the two wells. On the seismic panels, the sequence is characterized by a gently prograding interval which shows downlap at the sequence boundary (Fig. 5). The interval pinches-out towards the southwest, between the Borg-1/ Løgumkloster-1 and the Tønder-3 wells (Fig. 6). This interval is interpreted as representing the highstand systems tract of SJOM1. However, the prograding interval of SJOM1 may be subdivided into two sequences, where a sequence boundary is placed just below the internal flooding surface indicated in Løgumkloster-1, Brøns-1, and Borg-1 (Fig. 6).

The boundary between sequence SJOM1 and SJOM2 is placed at a low gamma ray response succeeded by a general upward increase in gamma log response. This surface is coincident with an unconformity identified on the seismic (boundary between seismic unit $\mathrm{A}$ and B) where truncation of the SJOM1 is seen in the northern part of the study area (Figs 4b-5). Above the truncated surface a very local prograding unit (Figs 4b-5) with steeply dipping clinothems downlaps the sequence boundary of SJOM1/SJOM2. The prograding interval with the steeply dipping clinothems and occasionally high amplitude reflectors, demonstrates a marked change in the depositional environment, probably a delta detached from a previous coast line. The delta shows a continous progradation during stable baselevel, consequently the interval is interpreted as a lowstand systems tract belonging to sequence SJOM2 and the lower sequence boundary is interpreted to be a Type 1 sequence boundary. Above this sequence boundary and the lowstand systems tract, the seismic pattern does not allow a detailed sequence stratigraphic subdivision but shows an overall onlapping thick interval of the seismic unit C (Fig. 4). Therefore, the following subdivision is based only on the $\log$ pattern. The transgressive systems tract of sequence SJOM2 is characterized by an upward increase in gamma log response and the maximum flooding surface is placed at high gamma response just below the overall decrease of the succeeding highstand systems tract (Fig. 6). The distinct gamma peak ca. 100 m higher is related to a bed with a high heavy mineral content and is thus not interpretated as a maximum flooding surface (Rud Friborg pers. comm. 1996). The boundary towards SJOM3 is placed at the lowest gamma log response, which corresponds to a sandy, lignite-rich horizon. The lignite is probably a result of reworking and consequently indicates a change in depositional environment probably including a basinward shift of the shoreline. However, whether there is a lowstand systems tract preserved here or whether marine erosion has resulted in a ravinement surface cannot be revealed from the present data. However, the evidence of a basinward shift of the shoreline indicate a Type 1 sequence boundary with lowstand deposits further basinwards. Sequence SJOM3 consist of a transgressive systems tract represented by the interval with an upward increasing gamma log response. The maximum flooding surface is recognized by a distinct gamma peak and is followed by a gradual upward decrease indicating progressively more coarse grained sediments of the succeeding highstand systems tract. The sequences SJOM4 to SJOM6 are similar to SJOM3 and defined on the same log criteria. The definition of the sequence boundaries, especially between SJOM5 and SJOM6, may need a more detailed description (see inserted section in Fig. 6). On top of the prograding highstand systems tract of SJOM5, a sharp boundary is seen and a blocky log pattern, characterized by low gamma response follows. This low gamma response corresponds to a sand or gravel layer in the Borg-1 well. This layer is overlain by an interval with a distinctly high gamma log response which again is succeeded by an interval with lower gamma response showing a gradual increasing upward trend. This part represents the transition from the Middle Miocene to the ?Late Miocene (see below). From several wells at Gram, located north of the study area (Dinesen 1976), the Middle-Upper Miocene deposits show a development which may result in the log pattern described above. At Gram, gravely sand of fluvio-lagustrine origin is transgressively superimposed by organic-rich estuarine sediments which again are succeeded by full ${ }^{\mathrm{u}}$ 


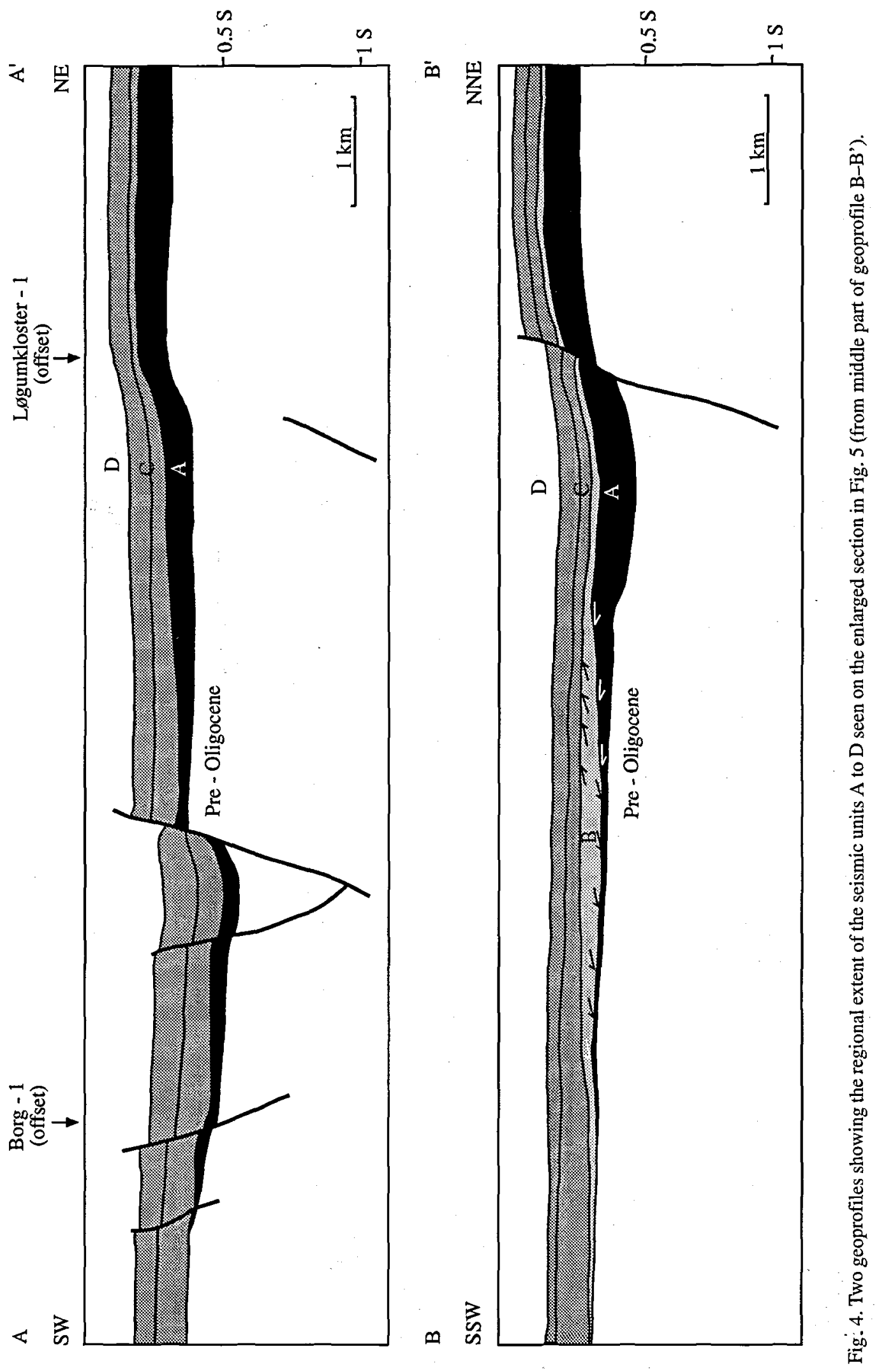



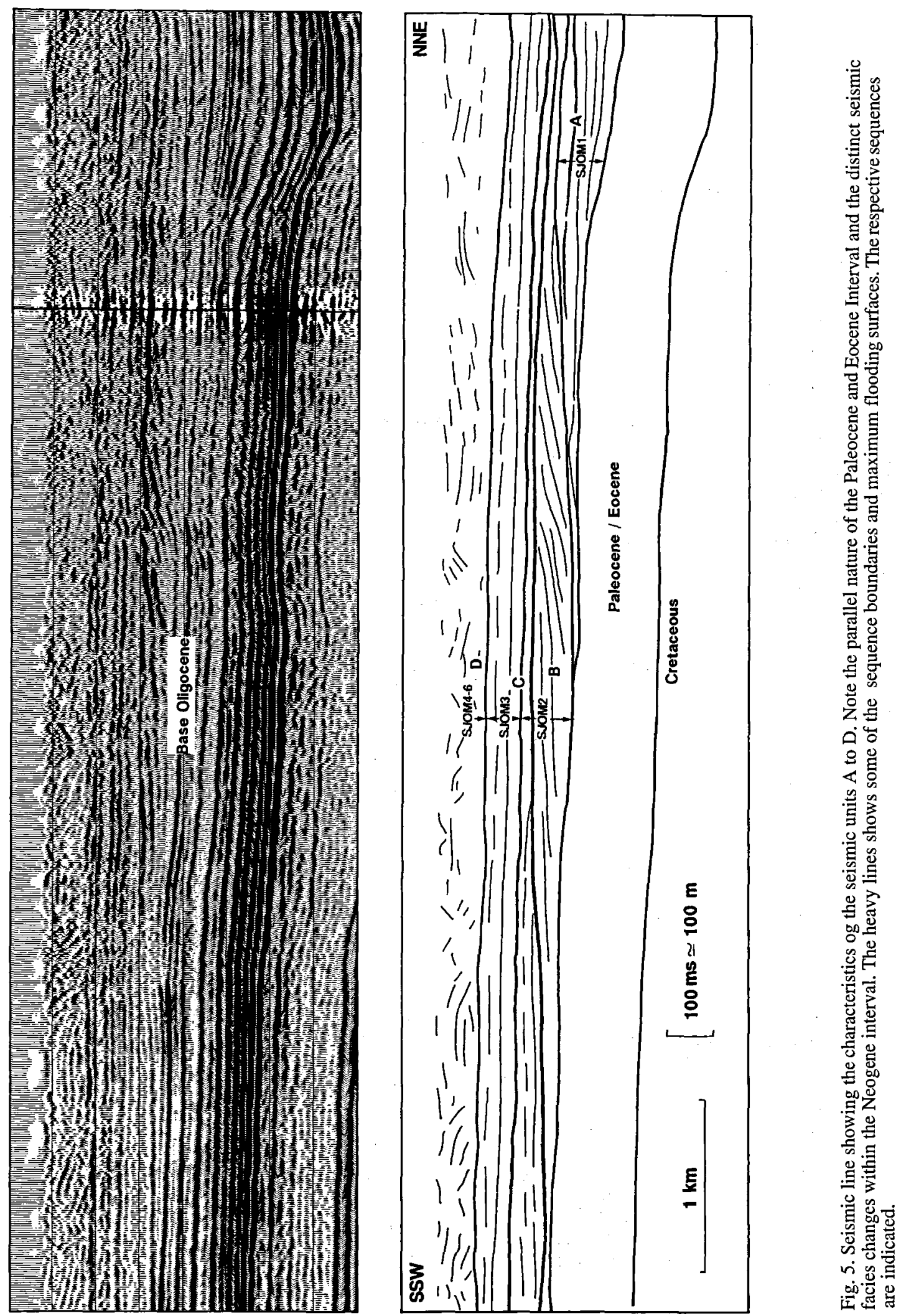


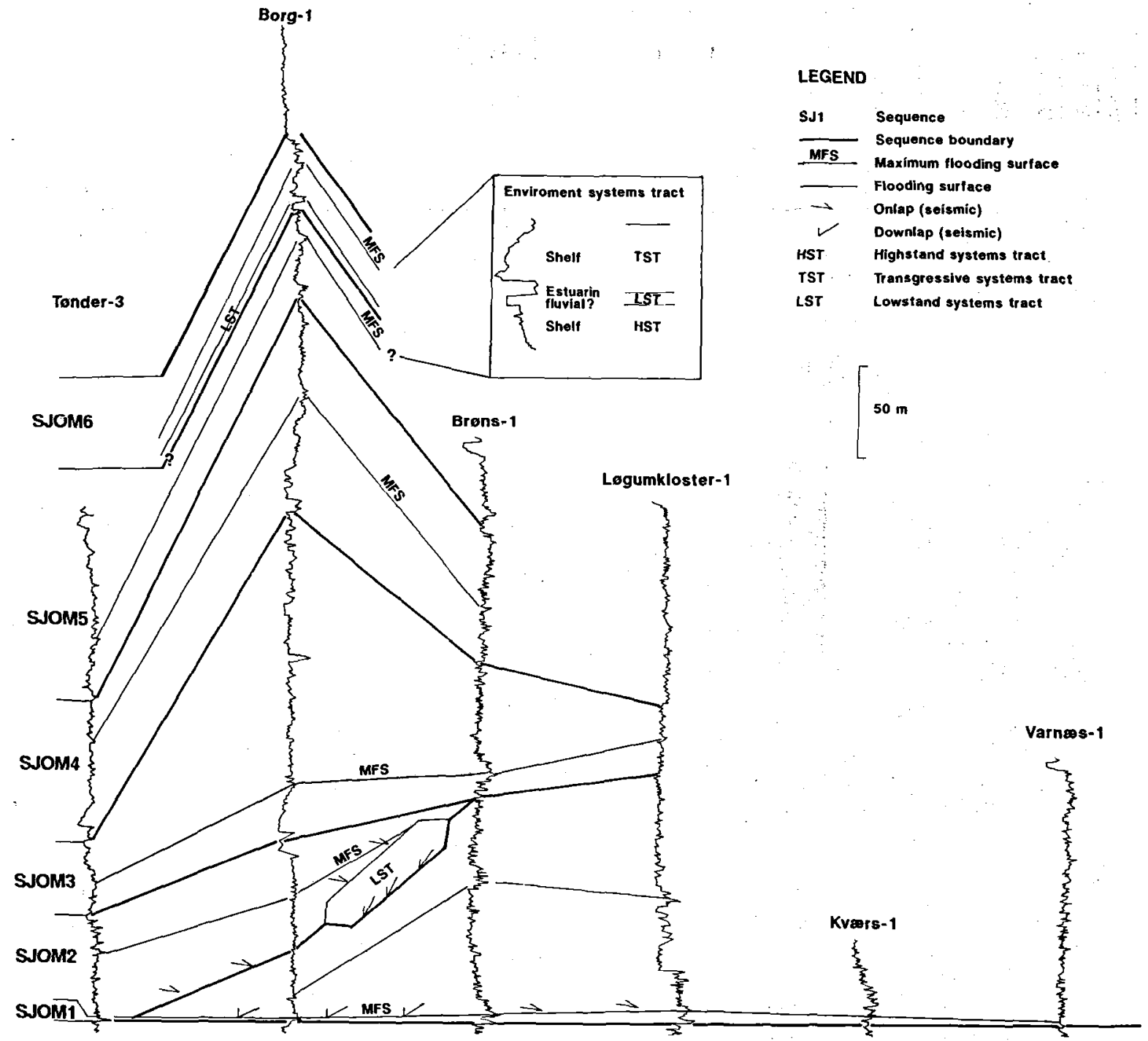

Fig. 6. Correlation of the six wells. The sequence names is shown to the left. A detailed section of the transition between sequence SJOM10/11 is shown in the frame, together with the depositional environment.

marine clays. Due to the sharp boundary between the gradual decreasing gamma log response of the highstand systems tract of SJOM5 in the Borg-1 well (Fig. 4) and the blocky log pattern of the gravely sand, the sequence boundary between SJOM5 and SJOM6 is placed here and the gravely sand layer is interpreted as a lowstand systems tract. Consequently, the boundary is interpreted as a Type 1 sequence boundary. A similar marked decrease in gamma log response is also seen within sequence SJOM1 in the Løgumkloster-1 well and thus should be a candidate for a sequence boundary here. However, this log pattern is only seen in the Løgumkloster-1 well in this study. From outcrops and other wells from East Jutland the development of this part of the strata seems to be dominated by a gradual increase of coarse-grained sediments, either by an increase in bed thickness of the sand layers or in grain size in an elsewhere totally bioturbated interval (Larsen \& Dinesen 1959, Rasmussen 1995). Consequently, this is interpreted to be a local phenom-: ena and not a regional event which should represent a sequence boundary.

\section{Stratigraphic framework}

Based on the above interpretations, a chronostratigraphic framework for the Oligocene and Miocene succession in South Jutland has been established (Fig. 7). 


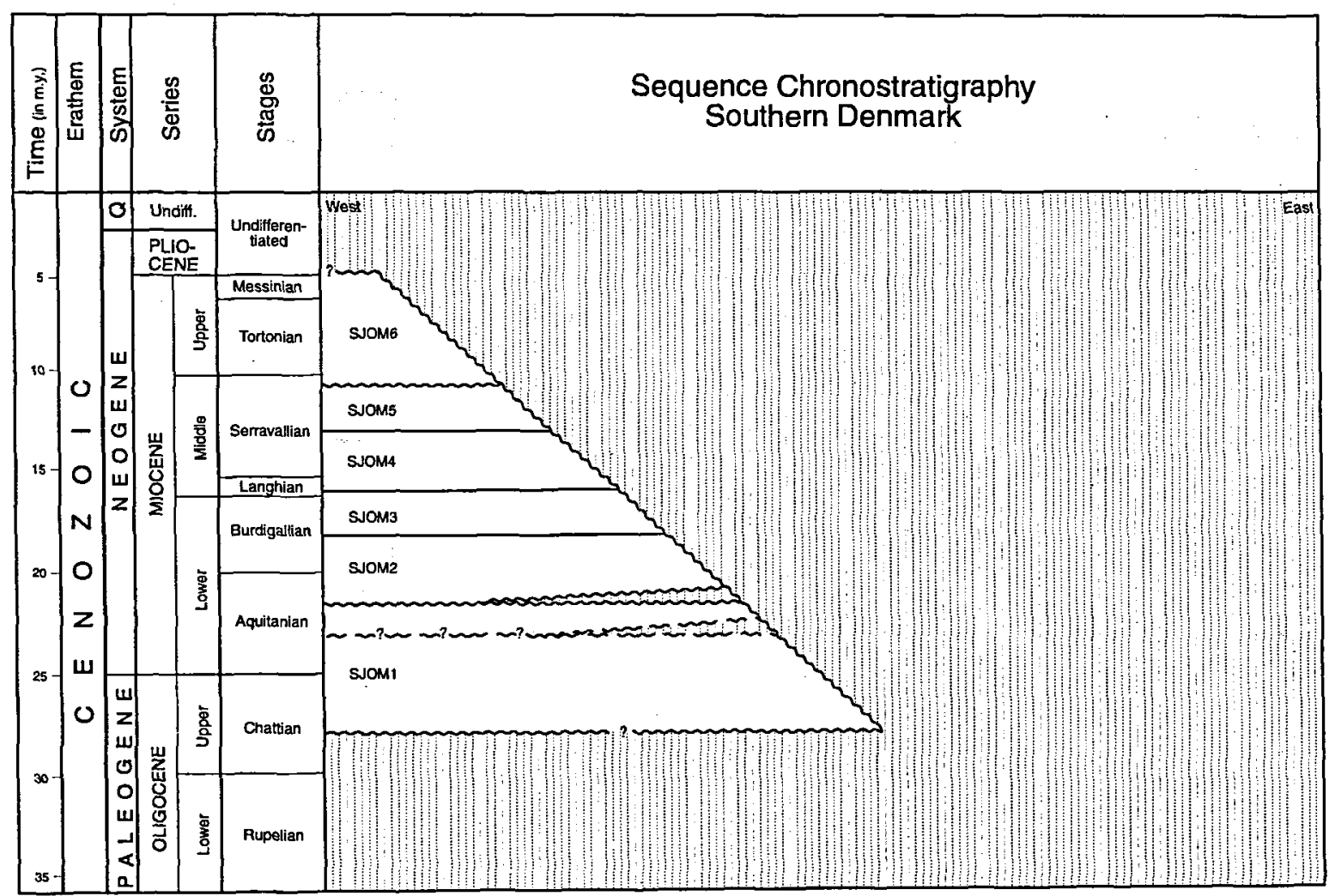

Fig. 7. Chronostratigraphic framework of the Tertiary succession onshore Denmark. The stippled boundary within SJOM1 indicate a futher subdivision of this sequence.

The succession is subdivided into six sequences, SJOM1 to SJOM6 and the datings is based on a biostratigraphic study of the Borg-1 well (Laursen 1995). The age of the lower sequence, SJOM1, is uncertain, but the similarities to the Vejle Fjord Formation is strong and a latest Late Oligocene to early Early Miocene age is likely (Ulleberg 1987). The age of sequence SJOM2 is also difficult to access but a fauna similar to the Vejle Fjord Formation has been found within this interval (pers. comm. Gitte Laursen 1994). The datings of the succeeding intervals are more precise. The maximum flooding surface of SJOM3 has been dated to late Burdigalian and samples form the transgressive systems tract of sequence SJOM4 indicate a Langhian/Serravallian age. The Highstand systems tract of SJOM4 has been dated to late Serravallian and the maximum flooding surface within sequence SJOM5 has been dated to latest Middle Miocene.

\section{Controls on sequence formation}

The formation of sequences is dependent on a number of processes, including eustatic sea-level variation, tectonics, climate, and sediment supply. These processes may be independent or partly dependent on one another.

The Neogene uplift of Fenno-Scandia (Jensen \& Schmidt 1992, Japsen 1993, Michelsen \& Nielsen 1993), which probably was initiated in the Oligocene, resulted in a major change in sediment supply and in deposition of relatively coarse-grained sediments during the late Tertiary. The main transport direction was from the northeast. From the present investigation it seems likely that the earliest outbuilding of sequences occurred stepwise by progradation of gently dipping clinoforms of probably shelf/offshore sediments referred to highstand systems tract. Basinward displacement of local prograding intervals, indicating a shift of the shoreline is interpretated as lowstand deposits. On the data used in the present study there is no indication of a sudden tilting or uplift of the area. However, there might have been salt movements at this time in the study area, but it seems not to be related to the recognized prograding feature. Another parameter involved in the changing types of progradational clinoforms may be variations in sediment influx, but one would expect a more smooth and continuous development of sequences and not a lateral displacement as 


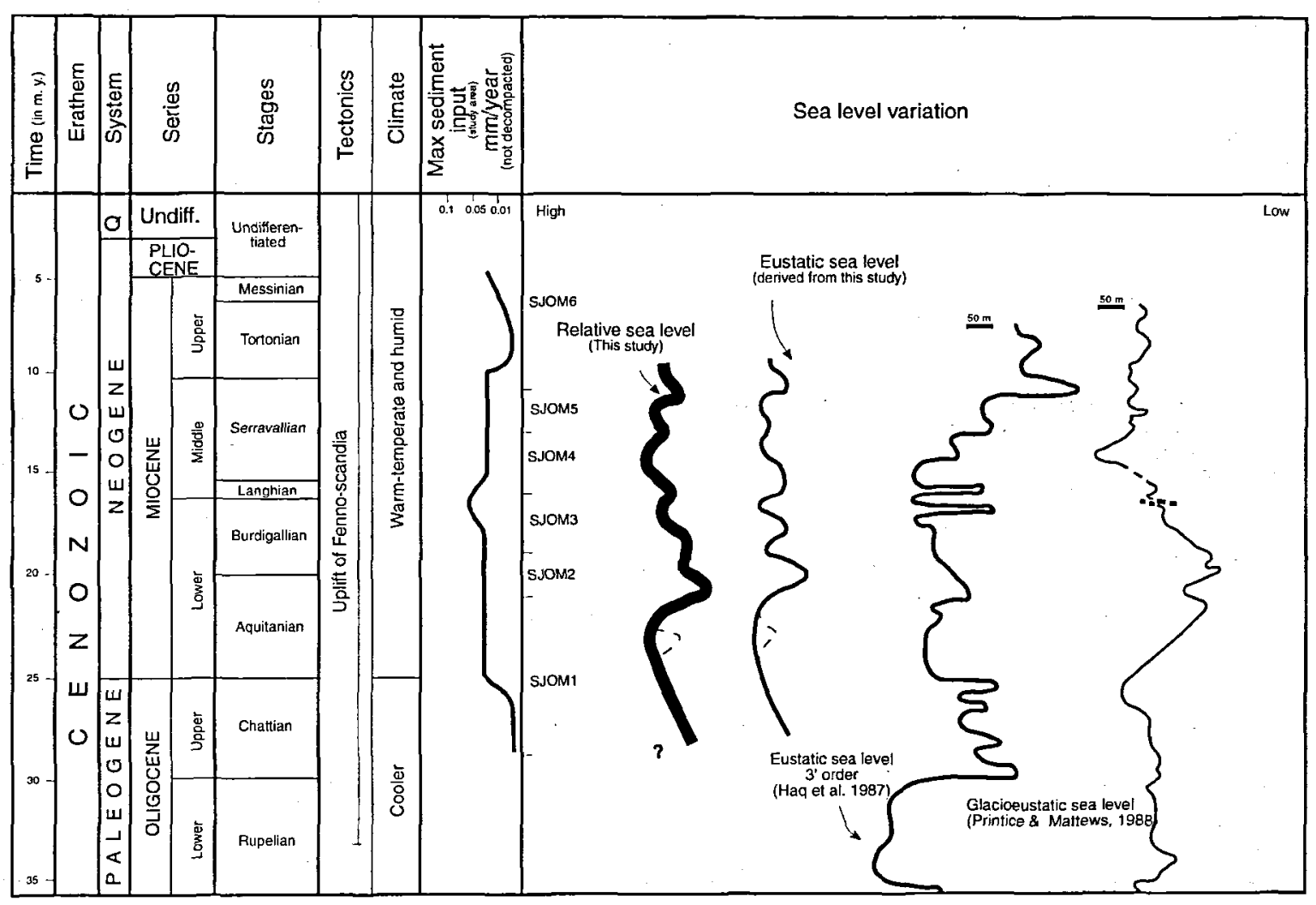

Fig. 8. A scheme showing tectonic events, climatic changes, sediment input, relative sea-level curves of South Denmark, and a possible eustatic sea-level curve derived from the relative sea level curve. In addition the eustatic sea level curve of Haq et al. (1987) and the glacio-eustatic sea-level curve of Prentice \& Matthews (1988) are also shown.

observed on the seismic data. Consequently, the most likely explanation for this evolution is changes in sealevel. A comparison to the glacio-eustatic sea-level curve of Prentice \& Matthews (1988) (Fig. 8), which also might be relevant for this time interval as major polar ice-caps presumably was formed in the Oligocene time (e.g. Bartek, Vail, Anderson, Emmet \& Wu 1991), show many similar trends. The most distinct lowstand of sea-level in the latest part of Aquitanian is recorded in both studies and probably further corresponds to the lowstand in latest Aquitanian of Haq, Hardenbol \& Vail (1987) and also recognized by Michelsen, Danielsen, Heilmann-Clausen, Jordt, Laursen \& Thomsen (in press) for the North Sea region. The general rise of sea-level during the Burdigalian, Langhian, and terminating in mid Serravallian as indicated in the sealevel curve of Prentice \& Matthews (1988) is also in line with the present study (Fig. 8) and corresponds to the overall onlapping interval recognized on seismic (Fig. 5) a similar trend seem also to characterized the evolution in the North Sea (Michelsen et al. in press.). The marked sea-level fall at the transition from the Middle Miocene to the Late Miocene revealed from this study also correspond to the sea-level fall picked in the early Late Miocene by Prentice \& Matthews
(1988) and also in the curve of Haq et al. (1987). As outlined above the study area seems to have been very sencitive to eustatic sea-level changes, especially on the order of third order sequences. However shifts in sediment supply associated with differential uplift of Fenno-Scandia and the Baltic area may have subdued the signals of sea-level changes and resulted in variations in the sedimentary architecture on a larger scale. For instance, a distinct progradation from east-northeast was recognised during the Early Miocene in the study area, corresponding to the regressive Ribe Formation (Rasmussen 1961, Koch 1989). In the northern North Sea, a marked progradation occurred from Norway in the mid Middle Miocene (Torben Bidstrup pers. comm. 1995, Jordt, Faleide, Bjørlykke \& Ibrahim 1995) and simultanious with transgression in South Jutland. A shift in sediment supply to a more easterly location again occurred in the Late Miocene associated with the progressively more sandy deposits of the Gram and Sæd Formations (Rasmussen 1961, Rasmussen \& Larsen 1989) and Mid to Late Miocene and Pliocene deltas in the southern North Sea (Cameron et al. 1993). Jordt et al. (1995) describe major seismic sequences in the Central North Sea as being tectonically controlled and it is likely that tectonic movements and 


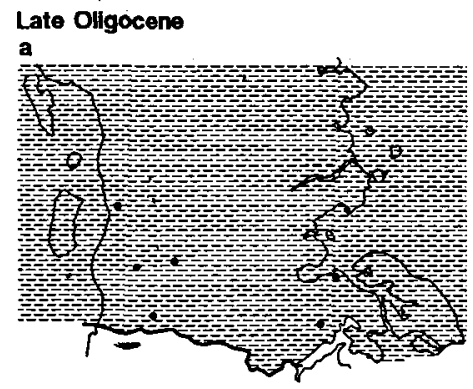

Early Miocene (early Aquitanian)
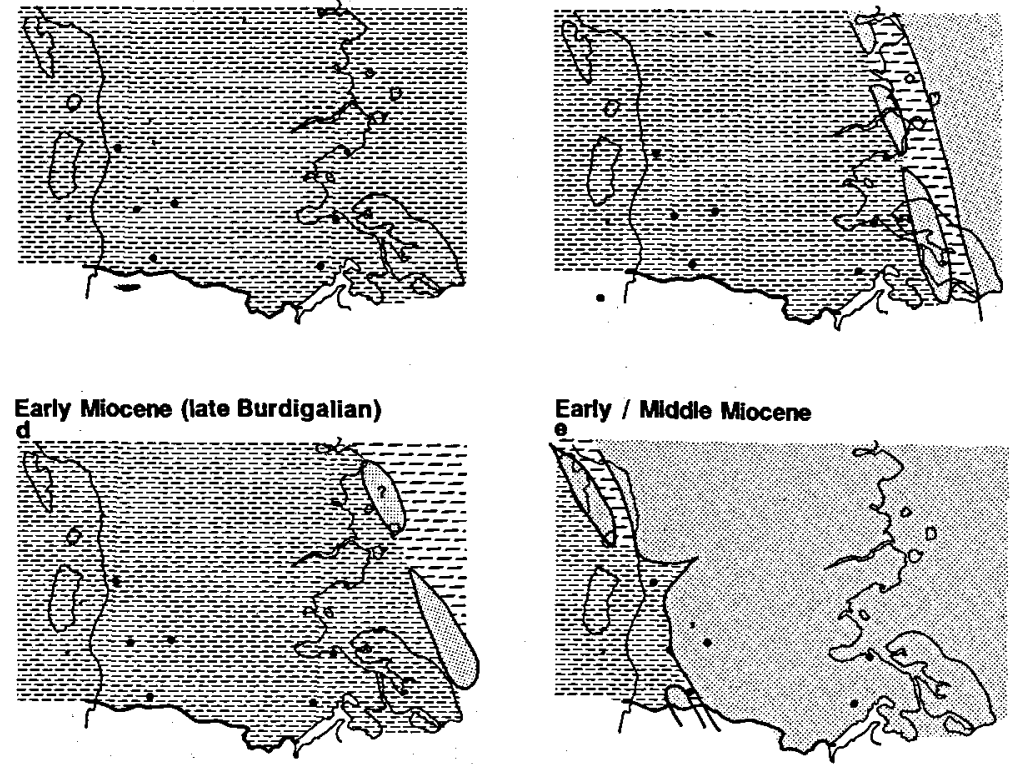

Middle / Late Miocene

g

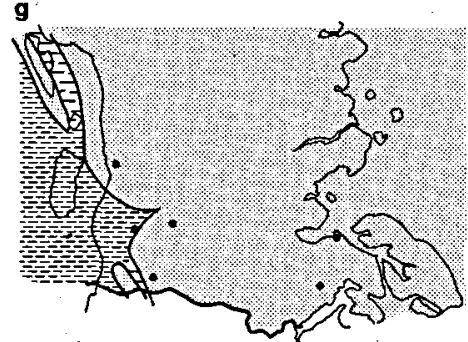

Early / Middle Miocene

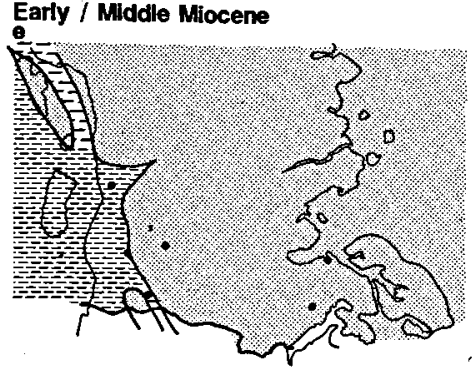

Late Miocene

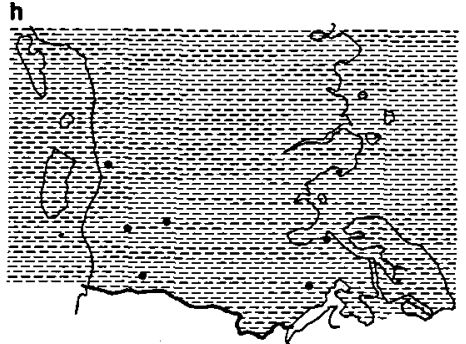

Middle Miocene (Late Serravallian)

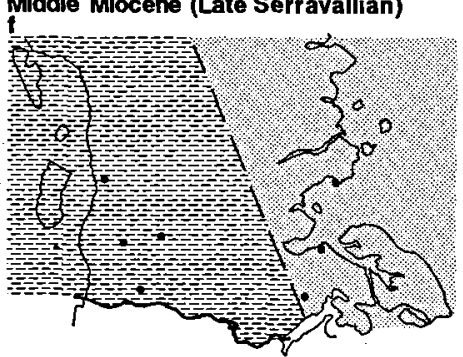

Pliocene

Early Mlocene (late Aquitanian)
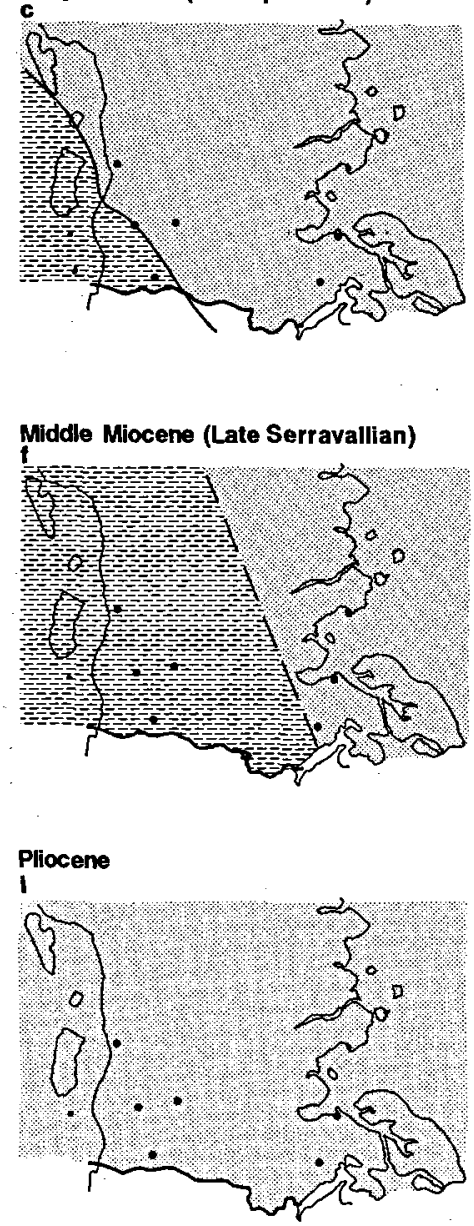

\section{Legend}

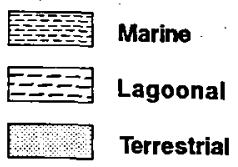

$10 \mathrm{~km} \quad \uparrow$

Fig. 9. Paleogeographical maps showing the dynamics of the Tertiary succession onshore south Denmark. Sources: Rasmussen (1995) and this study. 
flexual response govern the architecture on a second order (e.g. van Balen, van Beek \& Cloetingh 1995).

\section{Palaeogeography}

The present subdivision in sequences and thus in chronostratigraphic intervals provide an excellent tool for construction of palaeogeographic maps. However, these do not show the palaeogeography at certain surfaces (e.g. sequence boundaries or flooding surfaces) because that would result in maps either fully terrestial or fully marine. Instead maps representing time intervals have been reconstructed showing the dynamics of the depositional environment. Therefore, in the following the most important changes during the Tertiary are shown and thereby the overall dynamics of the depositional environment are illustrated (Fig. 9).

In latest Oligocene, most of Denmark was transgressed by the sea (Fig. 9a). The eastern extension of the sea cannot be documented, but from outcrops in eastern Jutland, coarse-grained sediments have been found (Larsen \& Dinesen 1959, Mikkelsen 1983, Rasmussen 1987) and consequently the shoreline was probably not located much farther east than the present eastcoast of Jutland. In the Early Miocene nearshore environments dominated South Jutland. The progradation of the shoreline occurred stepwise by successive development of barrier complexes. In the earliest part of the Early Miocene, the shoreline was located in East Jutland (Fig. 9b) (Radwanski, Friis \& Larsen 1975). Later, the progradation resulted in a nearshore depositional environment in southwest Jutland (Fig. $9 \mathrm{c})$. Periods with distinct basinward shift of the shoreline related to lowstand of sea-level occurred and locally, deltaic environments developed. The latest part of the Early Miocene (Fig. 9d) was characterized by an overall transgression. During the Middle Miocene, the coastline fluctuated across South Jutland (Figs 9e$9 \mathrm{f}-9 \mathrm{~g}$ ). In periods with lowstand of sea-level, the shoreline may have been located farther west than indicated on the figures. The transition from the Middle Miocene to the Late Miocene was characterized by a distinct basinward shift of the shoreline and in the Gram area, fluvial deposits have been reported (Dinesen 1976). The Upper Miocene deltas described by Cameron et al. (1993) located ca. $100 \mathrm{~km}$ southwest of the study area indicate the displacement of the shoreline during lowstand of sea-level. Successively, most of Denmark was transgressed and fully marine conditions were established (Fig. 9h) (Rasmussen 1966, Rasmussen \& Larsen 1989). In the latest Late Miocene and the Pliocene, there was an overall progradation of the shoreline and all of the southern Jutland became land area (Rasmussen \& Larsen 1989) (Fig. 9i).

\section{Conclussion}

The Oligocene and Miocene succession in South Jutland is composed of six sequences named SJOM1 to SJOM6. Most sequences is bounded by a type 1 sequence boundaries and thus Type 1 sequences. Eustatic sea-level changes is interpreted to be responsible on sequence formation of third order corresponding to SJOM1 to SJOM6. However, differential uplift of Fenno-Scandia and the Baltic area resulted in variation in sediment supply into the study area and consequently influenced the architecture of the Oligocene and Miocene Succession on a major scale. The eustatic sea-level changes resulted in fluxtuations of the shoreline across Jutland during the Oligocene and Miocene.

\section{Acknowledgement}

The author would like to thank Ron Steel, John Korstgård. Norsk Hydro A/S, The Danish Academy of Research, and The Geological Survey of Denmark is thanked for financial support. Alice Rosenstand and Gitte Nicolajsen drew the figures. I would also like to thank David Jutson for correcting the English. The two reviewer; Henrik Friis and Olaf Michelsen, gave valuable comments on the paper.

\section{Dansk sammendrag}

Den oligocæne og miocæne lagserie i Sønderjylland er inddelt i en sekvensstratigrafisk ramme. Studiet er baseret på en tolkning af seismiske data og petrofysiske borehulslogs fra boringerne; Tønder-3, Løgumkloster1, Borg-1, Brøns-1, Kværs-1 og Varnæs-1. Det sekvensstratigrafiske studie har medført en inddeling $i$ seks sekvenser benævnt SJOM-1 til SJOM6. Sekvenserne er hovedsageligt begrænset nedadtil af type 1 sekvensgrænser. Hver sekvens består af et lavtstandssystem, transgressivesystem og et højtstandssystem. Aflejringsmiljøet var karakteriseret ved skiftende afsætning af shelf sedimenter og kystnære/ fluviale sedimenter.

Udviklingen af sekvenserne er stærkt styret af glaciocustatiske havniveau ændringer, men en overordnet styring af lagserien er relateret til variationer $i$ sedimenttilførelsen forårsaget af tektoniske bevægelser i Det fennoskandiske Skjold i miocæn tid.

\section{References}

Bartek, L. R., Vail, P. R., Anderson, J. B., Emmet, P. A. \& Wu, S. 1991: Effect of Cenozoic Ice Sheet Fluctuations in Antartica on the Stratigraphic Signature of the Neogene. Journal of Geophycical Rescearch 96, 6753-6778.

Bonde, N. 1979: Palaeoenvironment in the "North Sea" as 
indicated by the fish bearing Mo-clay deposit (Paleocene/ Eocene), Denmark. Mededelingen van de Werkgroep voor Tertiaire en Kwartaire Geologie 16, 3-16.

Brown Jr., L. F. \& Fisher, W. L. 1980: Seismic Stratigraphy Interpretation and Petroleum Exploration. American Association of Petroleum Geologist. Continuing Education Course Note Series 16, 181 pp.

Buchardt, B. 1978: Oxygen isotope palaeotemperatures from the North Sea area. Nature 275, 121-123.

Buchardt-Larsen, B. \& Heilmann-Clausen, C. 1988: The Danish Subbasin, Southern Jutland. In Vinken, R. (Comp.), The Northwest European Tertiary Basin: Results of the International Geological Correlation Program No 124. Geologische Jahrbuch 100, 83-91.

Cameron, T. D. J., Bulat, J. \& Mesdag, C. S. 1993: High resolution seismic profile through a Late Cenezoic complex in the southem North Sea. Marine and Petroleum Geology 10, 591-599.

Christensen, L. \& Ulleberg, K. 1973: Sedimentology and micropalaeontology of the Middle Oligocene sequence at Sofienlund, Denmark. Bulletin of the Geological Society of Denmark 8, 283-305.

Christensen, L. \& Ulleberg, K. 1974: Sediments and foraminifers of the Middle Oligocene Viborg Formation, Denmark. Bulletin of the Geological Society of Denmark 23, 109-117.

Collison, M. E., Fowler, K. \& Boulter, M. C. 1981: Floristic changes indicate a cooling climate in the Eocene of southern England. Nature 291, 315-317.

Dinesen, A., Michelsen, O. \& Lieberkind, K. 1977: A survey of the Paleocene and Eocene deposits of Jylland and Fyn. Danmarks Geologiske Undersøgelse B 1, 15 pp.

Dinesen, B. 1976: Geochemical composition of the marine younger Miocene at Gram, SW Jutland. Danmarks Geologiske Undersøgelse Årbog 1975, 5-29.

Gripp, K. 1964: Erdgeschichte von Schleiswig-Holstein. 411 pp. Karl Wachholtz, Neumunster. Hansen. J. M. 1978: Age of the Mo-Clay Formation. Bulletin of the Geological Society of Denmark 27, 89-91.

Hansen, J. M. 1978: Age of the Mo-Clay Formation. Bulletin of the Geological Society of Denmark 27. 89-91.

Haq, B. U., Hardenbol, J. \& Vail, P. R. 1987: Chronology of Fluctuating Sea Levels Since the Triassic. Science 235, 1156-1167.

Heilmann-Clausen, C., Nielsen, O. B. \& Gersner, F. 1985: Lithostratigraphy and depositional environments in the Upper Oaleocene and Eocene of Denmark. Bulletin of the Geological Society of Denmark 33, 287-323.

Helland-Hansen, W. \& Gjelberg, J. 1994: Conceptual basis and arriability in sequence stratigraphy: a different perspective. Sedimenntary Geology 92, 31-52.

Hunt, D. \& Tucker, M.E. 1992: Stranded parasequences and forced regressive wedge systems tract: deposition during base-leve fall. Sedimentary Geology 81, 1-9.

Japsen, P. 1993: Influence of Lithology and Neogene Uplift on Seismic Velocities in Denmark: Implications for Depth Conversion of Maps. Bulletin of American Association of Petroleum Geologist 77, 194-211.

Jensen, L. N. \& Schmidt, B. J. 1992: Late Tertiary uplift and erosion in the Skagerrak area: magnitude and consequences. Norsk Geologisk Tidsskrift 72, 275-279.

Jervey, M. T. 1988: Quantitative geological modeling of siliciclastic rock sequences and their seismic expression. Special Publication of the Society of Economic Paleontologist and Mineralogists 42, 47-69.
Knox, R. W. O'B. \& Holloway, S. 1992: Paleogene of the Central and Northern North Sea. In R. W. O'B Knox \& W. G. Cordey (Eds), Lithostratigraphic nomenclature of the UK North Sea. British Geological Survey, 133 pp.

Knox, R. W. O’B., Morton, A. C. \& Harland, R. 1981: Stratigraphical relationships of Paleogene sands in the UK Sector of the Central North Sea. In: Illing, L. V. and Hobson, G. D. (Eds) Petroleum Geology of the Continental Shelf of North-West Europe. Institute of Petroleum, London, 267-281.

Koch, B. E. 1989: Geology of the Søby-Fasterholt area. Danmarks Geologiske Unders $\emptyset$ gelse A 22, 170 pp.

Larsen, G. \& Dinesen, A. 1959: Vejle Fjord Formationen ved Brejning. Sedimenterne og foraminiferfaunaen (Oligocæn-Miocæn). Danmarks Geologiske Undersøgelse II Række 82, 114 pp.

Laursen, G. V. 1995: Foraminiferal analyses of Tertiary deposits in the North Sea area. Unpublished Ph.D. dissertation, Aarhus University, $276 \mathrm{pp}$.

Liboriussen, J., Ashton, P. \& Tygesen, T. 1987: The tectonic evolution of the Fennoscandian Border Zone in Denmark. Tectonophysics 137, 21-29.

Michelsen, O. \& Nielsen, L. H. 1993: Structural development of the Fennoscandian Border Zone, offshore Denmark. Marine and Petroleum Geology 10, 124-134.

Michelsen, O., Danielsen, M., Heilmann-Clausen, C., Jordt, H. \& Laursen, G. V. \& Thomsen, E. In Press: Cenozoic sequence stratigraphy in the eastern North Sea. In: Mesozoic- Cenozoic sequence stratigraphy of Western European Basin In de Graciansky, P. Ch. \& Vail, P. R.(Eds) 2. Society of Economic Paleontologist and Mineralogist, Tulsa.

Middelburg, J. J., Calvet, S. E. \& Karlin, R. 1991: Organicrich transitional facies in silled basins: Response to sealevel change. Geology 19, 679-682.

Mikkelsen, J. 1983: En lithofacies undersøgelse af ungtertiæret omkring Vejle Fjord. Unpublished Thesis, 90 pp. Aarhus Universitet.

Pedersen, G. K. \& Surlyk, F. 1983: The Fur Formation, a late Paleocene ash-bearing diatomite from northern Denmark. Bulletin of the Geological Society of Denmark 32, 43-65.

Posamentier, H. W. \& Vail, P. R. 1988: Eustatic Controls on Clastic Deposition II-Sequence and Systems Tract Models. Special Publication of the Society of Economic Paleontologists and Mineralogists 42, 125-154.

Posamentier, H. W., Jervey, M. T. \& Vail, P. R. 1988: Eustatic Controls on Clastic Deposition I-Conceptual Framework. Special Publication of the Society Economic Paleontologists and Mineralogists 42, 109-124.

Prentice, M. L. \& Matthews, R. K. 1988: Cenozoic ice-volume history: Development of a composite oxygene isotope record. Geology 16, 963-966.

Radwanski, A. Friis, H. \& Larsen, G. 1975: The Miocene Hagenør-Børup sequence at Lillebælt. Bulletin Geological Society of Denmark 24, 283-297.

Rasmussen, E. S. 1987: En mineralogisk og geokemisk undersøgelse af Vejle Fjord Formationen ( $\varnothing$. OligocænN. Miocæn). Unpiblished M.Sc. thesis pp. 214, Aarhus University.

Rasmussen, E. S. \& Larsen, O. H., 1989: Mineralogi og geokemi af det $\varnothing$ vre Miocæne Gram ler. Danmarks Geologiske Unders $\emptyset$ gelse D 7, $81 \mathrm{pp}$.

Rasmussen, E. S. 1995: Mineralogy and geochemistry of 
the Vejle Fjord Formation. Bulletin of the Geological Society of Denmark 42, 53-62.

Rasmussen, L. B. 1961: De miocene formationer i Danmark. Danmarks Geologiske Unders øgelse IV Række, 5, 45 pp.

Rohrman, M., Andriessen, P., \& van der Beek, P. 1996: The relationship between basin and margin thermal evolution assessed by fission track thermochronology: and application to offshore southern Norway. Basin Research 8, 45-63.

Sandersen, P. 1985: En sedimentologisk undersøgelse af ungterti ret langs den nordlige del af Lillebælt. Unpublished M. Sc. Thesis, 210 pp. Aarhus Universitet.

Sorgenfrei, T. 1940: Marint nedre mioc n i Klintinghoved paa Als. Danmarks Geologiske Undersøgelse II Rakke, $65,143 \mathrm{pp}$.

Sorgenfrei, T. 1951: Oversigt over prækvartærets topografi, stratigrafi og tektonik i området Fyn- Sydsjælland-Lolland-Falster-Møn. Meddelser fra dansk geologisk Forening 12, 166-171.

Sorgenfrei, T. 1958: Molluscan assemblages from the marine Middle Miocene of South Jutland and their environments. Danmark Geologiske Unders $\emptyset$ gelse II række, 79, 503 pp.

Ulleberg, K. 1987: Foraminiferal zonation of the Danish Oligocene sediments. Bulletin of the Geological Society of Denmark 36, 191-202.

Vail, P. R., Mitchum, R. M., Todd, R. G., Widmier, J. M., Thompson, S., III, Sangree, J. B., Bubb, J. N. \& Hatelid, W. G. 1977: Seismic stratigraphy and global changes of sea level. In Payton C. E. (Ed.) Seismic Stratigraphy-Application to Hydrocarbon Exploration. American Association of Petroleum Geology, Memoir 26, 49-212.

van Balen, R. T., van der Beek, P. A., \& Cloetingh, S. A. P. L. 1995: The effect of rift shoulder erosion on stratal patterns at passive margins: Implications for sequence stratigraphy. Earth and Planetary Science Letters 134, 527544 .

van Wagoner, J. C., Mitchum, R. M., Campion, K. M., \& Rahmanian, V. D. 1990: Siliciclastic Sequence Stratigraphy in Well Logs, Cores, and Outcrops. American Association of Petroleum Geologists Methods in Exploration $7,55 \mathrm{pp}$.

Ziegler, P. A. 1982: Geological atlas of Western and Central Europe. Elsevier, Amsterdam, 130 pp. 